\title{
Pemanfaatan Data Landsat-8 dan MODIS untuk Identifikasi Daerah Bekas Terbakar Menggunakan Metode NDVI (Studi Kasus: Kawasan Gunung Bromo)
}

\author{
Nurul Aini Dan Bangun Muljo Sukojo \\ Jurusan Teknik Geomatika, Fakultas Teknik Sipil dan Perencanaan, Institut Teknologi Sepuluh \\ Nopember (ITS) \\ Jl. Arief Rahman Hakim, Surabaya 60111 Indonesia \\ e-mail: bangunms@gmail.com,20.nurulaini@gmail.com
}

\begin{abstract}
Abstrak - Kebakaran hutan dan lahan merupakan masalah serius yang kerap terjadi di beberapa wilayah Indonesia. Kebakaran terjadi akibat faktor alam atau bahkan karena unsur kesengajaan manusia. Salah satu contoh kasus kebakaran adalah kebakaran hutan savana di kawasan Gunung Bromo pada tanggal 20 sampai 23 Oktober 2014. Kebakaran yang berlangsung selama empat hari tersebut telah menghanguskan kurang lebih 1.487 Ha. Kondisi tersebut menunjukkan bahwa kebakaran merupakan ancaman serius karena kerugian yang ditimbulkannya. Oleh sebab itu, perlu dilakukan upaya penanganan pasca kebakaran. Salah satu caranya adalah penyediaan informasi spasial daerah bekas terbakar dalam bentuk peta. Peta dibuat dengan memanfaatkan data penginderaan jauh yaitu citra Landsat-8 dan citra MODIS sebelum dan sesudah kebakaran. Daerah bekas terbakar diidentifkasi dengan metode NDVI (Normalized Difference Vegetation Index). NDVI memanfaatkan kanal inframerah dekat dan kanal merah untuk menganalisa kerapatan vegetasi. Suatu piksel diklasifikasi sebagai daerah bekas terbakar jika nilainya melebihi nilai threshold. Model threshold yang digunakan dalam penelitian ini adalah $\mu-1 \sigma$, $\mu$, dan $\mu+1 \sigma$. Berdasarkan hasil identifikasi daerah bekas terbakar pada kedua citra, didapat nilai akurasi terbesar citra Landsat-8 adalah $48,394 \%$ dari model $\mu$ - $1 \sigma$ sedangkan citra MODIS adalah $57,089 \%$ dari model $\mu$. Luas daerah bekas terbakar untuk citra Landsat-8 sebesar 1.354,5 Ha sedangkan untuk citra MODIS sebesar 1.005,209 Ha.
\end{abstract}

Kata Kunci-Landsat-8, MODIS, NDVI, Threshold, Uji akurasi

\section{PENDAHULUAN}

$\mathrm{M}$ ENURUT Badan Nasional Penanggulangan Bencana, kebakaran hutan dan lahan adalah suatu keadaan di mana hutan dan lahan dilanda api, sehingga mengakibatkan kerusakan hutan dan lahan yang menimbulkan kerugian ekonomis dan atau nilai lingkungan. Pada musim kemarau, kebakaran sering terjadi di beberapa wilayah Indonesia. Kebakaran terjadi akibat faktor alam atau bahkan karena unsur kesengajaan manusia. Salah satu contoh kebakaran adalah kebakaran hutan dan lahan yang terjadi di kawasan Gunung Bromo pada tanggal 20 sampai 23 Oktober 2014. Kebakaran tersebut menghanguskan kurang lebih $1.487 \mathrm{Ha}$ hektar hutan savana. Kondisi tersebut menunjukkan bahwa kebakaran merupakan ancaman serius karena kerugian besar yang diakibatkannya.
Oleh sebab itu, perlu dilakukan upaya penanganan pasca kebakaran seperti penyediaan informasi spasial daerah bekas terbakar. Perolehan informasi ini dapat dilakukan dengan memanfaatkan data penginderaan jauh. Data penginderaan jauh yang dapat digunakan untuk identifikasi daerah bekas terbakar adalah citra Landsat-8 dan citra MODIS. Landsat 8 merupakan satelit yang dilengkapi oleh dua sensor, yakni OLI yang terdiri dari 9 kanal dan TIRS yang terdiri dari 2 kanal. Citra Landsat 8 memiliki resolusi temporal 16 hari dan resolusi spasial $15 \mathrm{~m}$ pankromatik, $30 \mathrm{~m}$ multispektral, $60 \mathrm{~m}$ termal. Citra MODIS adalah hasil perekaman sensor MODIS dari Satelit Terra/Aqua. Sensor MODIS memiliki 36 kanal, dimana kanal 1 dan 2 memiliki resolusi spasial $250 \mathrm{~m}$, kanal 3 sampai 7 memiliki resolusi spasial $500 \mathrm{~m}$ dan kanal 8 sampai 36 memiliki resolusi spasial $1000 \mathrm{~m}$ [1].

Daerah bekas terbakar diidentifikasi dengan menggunakan metode NDVI. NDVI (Normalized Difference Vegetation Index) memanfaatkan kanal inframerah dekat dan kanal merah untuk menganalisa kerapatan vegetasi. Metode NDVI dipilih karena resolusi spasial kanal yang digunakan dirasa sesuai dengan daerah penelitian yang kecil, yakni $30 \mathrm{~m}$ untuk citra Landsat 8 dan $250 \mathrm{~m}$ untuk citra MODIS. Perbedaan resolusi spasial tersebut akan mengakibatkan perbedaaan hasil identifikasi daerah bekas terbakar. Selain itu perbedaan hasil juga diakibatkan oleh threshold yang digunakan. Identifikasi dilakukan dengan menggunakan tiga model threshold sehingga setiap citra menghasilkan tiga peta daerah bekas terbakar yang berbeda. Oleh karena itu, perlu dilakukan uji akurasi setiap model threshold dari citra Landsat-8 dan citra MODIS untuk mendapatkan hasil identifikasi daerah bekas terbakar dengan nilai akurasi paling tinggi.

\section{METODOLOGI PENELITIAN}

\section{A. Lokasi Penelitian}

Penelitian dilakukan di kawasan Gunung Bromo yang berada dalam empat kabupaten yaitu Probolinggo, Pasuruan, Lumajang, dan Malang. Kawasan Gunung Bromo dikelola oleh Balai Besar Taman Nasional Bromo Tengger Semeru (BB TNBTS). Secara geografis terletak pada $7^{\circ} 56^{\prime} 30^{\prime \prime} \mathrm{LU}$ $112^{\circ} 57^{\prime} 00^{\prime \prime} \mathrm{BT}$. 


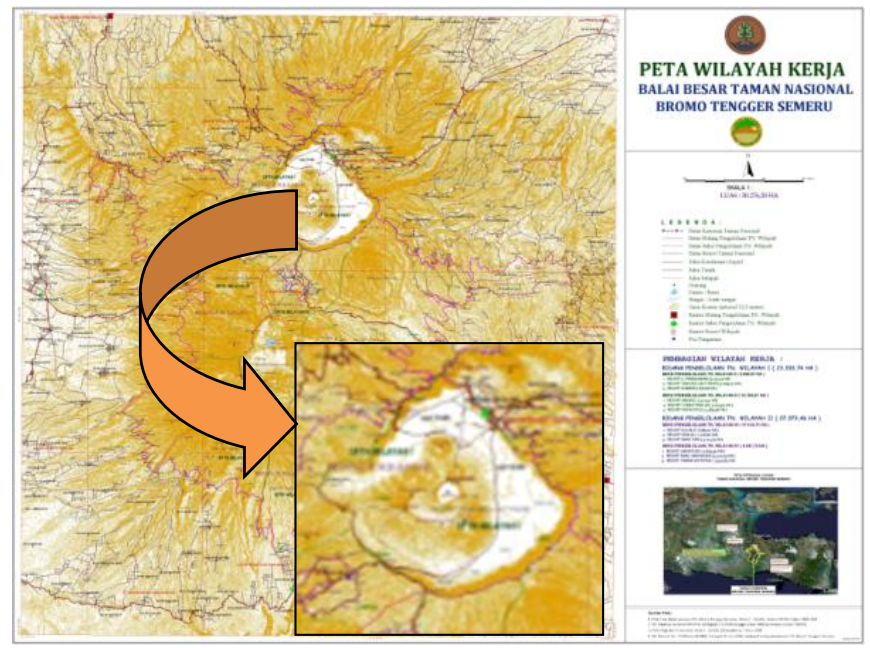

Gambar 1. Lokasi penelitian

(Sumber: Balai Besar Taman Nasional Bromo Tengger Semeru)

\section{B. Data yang Digunakan}

Penelitian menggunakan data citra Landsat-8 L1T, citra MODIS Level 1B, laporan kejadian kebakaran BB TNBTS bulan Oktober 2014, peta wilayah kerja BB TNBTS, peta batas administrasi jawa timur, dan data groundtruth.

\section{Tahap Pengolahan}

Berikut penjelasan diagram alir pengolahan:

1. Data Citra

Citra yang digunakan adalah citra Landsat-8 L1T dan citra MODIS Level 1B sebelum dan sesudah terjadinya kebakaran. Tanggal terjadinya kebakaran didapat dari laporan kejadian kebakaran BB TNBTS bulan Oktober 2014. Citra Landsat-8 yang digunakan adalah citra pada tanggal 3 Oktober 2014 dan 4 November 2014. Sedangkan citra MODIS yang digunakan adalah citra pada tanggal 27 Agustus 2014 dan 3 November 2014.

\section{Georeferencing}

Georeferencing merupakan proses pemberian sistem koordinat dari citra yang belum mempunyai acuan sistem koordinat ke dalam sistem koordinat dan proyeksi tertentu. Georeferencing hanya dilakukan untuk citra MODIS.

\section{Koreksi Radiometrik}

Koreksi radiometrik meliputi kalibrasi radiometric yang bertujuan untuk mengubah nilai Digital Number menjadi reflektan dan koreksi atmosferik yang bertujuan untuk menghilangkan efek atmosfer pada nilai reflektan citra.

4. Pemotongan Citra

Pemotongan citra dilakukan untuk mendapatkan daerah penelitian dan memfokuskan pengolahan data pada daerah tersebut. Citra dipotong berdasarkan area Seksi Pengelolaan
Taman Nasional Wilayah 1 Resort Tengger Laut Pasir pada peta wilayah kerja BB TNBTS.

\section{Perhitungan Nilai NDVI}

NDVI (Normalized Difference Vegetation Index) merupakan indeks vegetasi yang menghasilkan citra representatif untuk analisa kerapatan vegetasi. NDVI juga dapat digunakan untuk mengidentifikasi daerah bekas terbakar. Persamaan NDVI berdasarkan metode Huete et al. [2] adalah:

$$
\text { NDVI }=\frac{\text { NIR }- \text { Red }}{\text { NIR }+ \text { Red }}
$$

Perhitungan NDVI akan menghasilkan nilai $\mathrm{NDVI}_{1}, \mathrm{NDVI}_{2}$, dan $\triangle$ NDVI. $\mathrm{NDVI}_{1}$ dihitung dari citra sebelum kebakaran sedangkan $\mathrm{NDVI}_{2}$ dihitung dari citra sesudah kebakaran. $\triangle$ NDVI dihitung dari persamaan berikut:

$$
\Delta \mathrm{NDVI}=\mathrm{NDVI}_{1}-\mathrm{NDVI}_{2}
$$

6. Penentuan Threshold

Threshold (nilai ambang batas) akan menentukan tingkat akurasi hasil daerah bekas terbakar. Penentuan threshold dilakukan dengan menghitung rata-rata $(\mu)$ dan standar deviasi $(\sigma)$ nilai reflektan citra sebelum dan sesudah kebakaran. Mengacu pada Fraser et al. (2000), model threshold yang akan digunakan adalah $\mu-1 \sigma, \mu, \mu+1 \sigma$.

7. Identifikasi Daerah Bekas Terbakar

Identifikasi daerah bekas terbakar dilakukan dengan menggunakan nilai $\Delta$ NDVI dan threshold. Persamaan untuk mendapatkan daerah bekas terbakar adalah:

$$
\mathrm{BA}=\Delta \mathrm{NDVI}>\text { Threshold }
$$

dimana BA adalah Burned Area (daerah bekas terbakar).

8. Uji Akurasi

Uji akurasi dilakukan dengan membandingkan hasil identifikasi daerah bekas terbakar (estimated burned area) dengan data daerah bekas terbakar referensi (referenced burned area). Berdasarkan data estimated burned area dan referenced burned area, dapat dihitung data valid, omisi, dan komisi. Data valid adalah data estimated burned area yang sesuai dengan referenced burned area. Omisi adalah burned area (pada estimasi) yang dinyatakan sebagai non-burned area (pada referensi). Komisi adalah non-burned area (pada estimasi) yang dinyatakan sebagai burned area (pada referensi). Uji akurasi dihitung dengan persamaan berikut

Akurasi keseluruhan $(\%)=\frac{V \times 100 \%}{V+O+K}$

Dimana $V$ adalah data valid, $O$ adalah data kesalahan omisi, dan $\mathrm{K}$ adalah data kesalahan komisi.

9. Peta

Informasi daerah bekas terbakar disajikan dalam bentuk peta yang sesuai dengan kaidah kartografi. Peta dibuat dari model threshold yang memiliki nilai akurasi paling besar. 


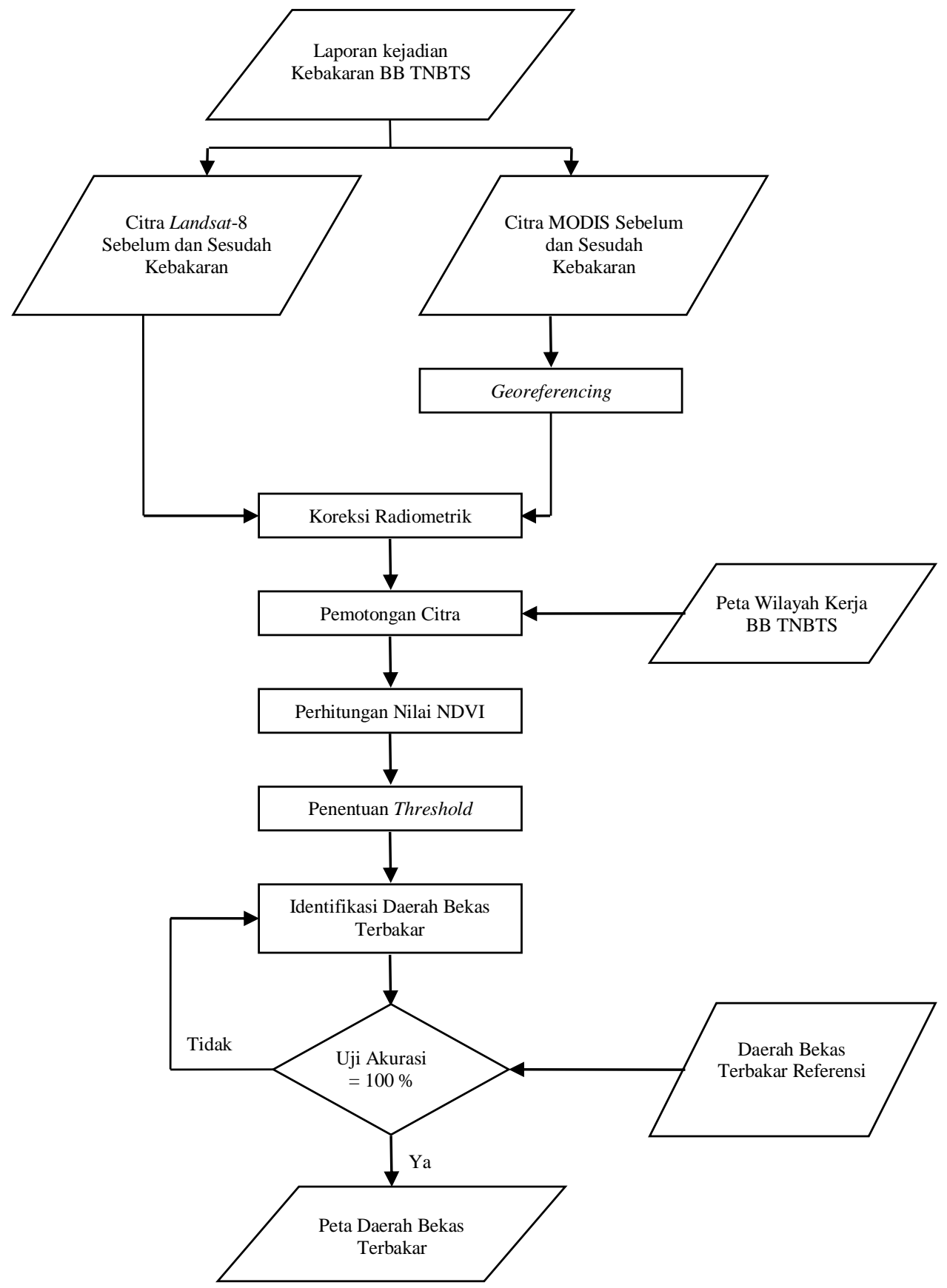

Gambar 2. Diagram alir pengolahan

\section{HASIL DAN ANALISA}

\section{A. Prakiraan Daerah Bekas Terbakar}

1. Kombinasi Kanal

Daerah bekas terbakar diprakirakan dengan melakukan interpretasi visual, yaitu kombinasi kanal citra Landsat-8. Adapun kombinasi yang digunakan antara lain color infrared (vegetation), healthy vegetation dan vegetation analysis. Kombinasi tersebut dapat digunakan untuk mengetahui vegetasi yang sehat dan vegetasi yang tidak sehat (bekas terbakar).
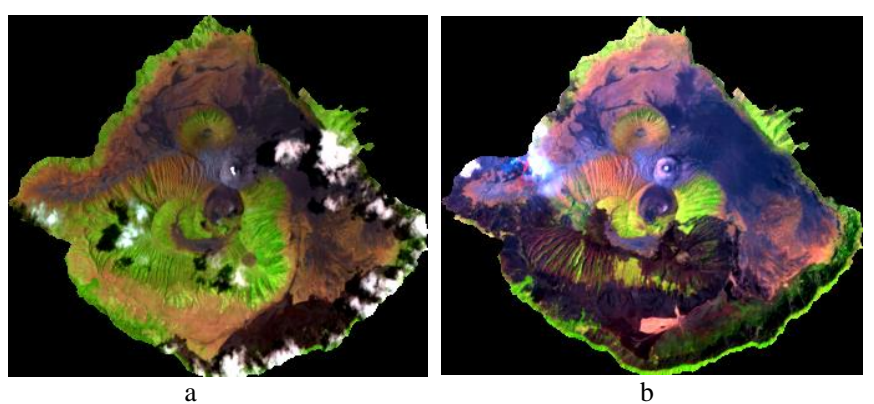

Gambar 3. Kombinasi vegetation analysis citra sebelum (a) dan sesudah kebakaran (b)

\section{Laporan Kejadian Kebakaran BB TNBTS}

Laporan kejadian menyatakan telah terjadi kebakaran pada tanggal 20 s/d 23 Oktober 2014. Luas daerah yang terbakar \pm 
1.487 Ha pada Blok Teletubbies, Gunung Watangan, Gunung Kursi, Adasan, dan Keciri yang berada di Wilayah Kerja Resort Tengger Laut Pasir. Jenis vegetasi yang terbakar antara lain adas, akasia, edelweis, kemlandingan gunung, ladingan, mentigi gunung, cemara gunung, rumput alang-alang, rumput merak, rumput empritan, paku ekor kuda, dan pakis hutan.

Tabel 1.

Koordinat lokasi daerah bekas terbakar wilayah kerja resort tengger laut pasir

\begin{tabular}{|c|c|c|}
\hline Lokasi & \multicolumn{2}{|c|}{ Koordinat } \\
\hline Blok Watu Gedhe & $07^{0} 58^{\prime} 42.3 " \mathrm{~s}$ & $112^{0} 56^{\prime} 33.4^{\prime \prime} \mathrm{E}$ \\
\hline Blok Jemplang & $07^{\circ} 58^{\prime} 27.4$ " S & $112^{0} 55^{\prime} 35.4$ " E \\
\hline D10l Tolotubhio & $07^{\circ} 58^{\prime} 38.9 " \mathrm{~S}$ & $112^{\circ} 56^{\prime} 50.0^{\prime \prime} \mathrm{E}$ \\
\hline Blok Teletubbies & $07^{\circ} 58^{\prime} 30.4^{\prime \prime} \mathrm{S}$ & $112^{0} 56^{\prime} 51.7$ ' E \\
\hline Blok Adasan & $07^{0} 58^{\prime} 30.4 " \mathrm{~S}$ & $112^{0} 57^{\prime} 17.2^{\prime \prime} \mathrm{E}$ \\
\hline D1ol Ponare & $07^{0} 58^{\prime} 14.5^{\prime \prime} \mathrm{S}$ & $112^{0} 57^{\prime} 48.6$ " E \\
\hline & $07^{\circ} 57^{\prime} 50.7^{\prime \prime} \mathrm{S}$ & $112^{0} 58^{\prime} 01.7 " \mathrm{E}$ \\
\hline Blok Gunung Kursi & $07^{\circ} 57^{\prime} 14.2 " \mathrm{~s}$ & $112^{0} 57^{\prime} 58.99^{\prime \prime} \mathrm{E}$ \\
\hline
\end{tabular}

\section{Groundtruth}

Pada penelitian ini, groundtruth dilakukan dengan mengambil koordinat beberapa titik yang dinyatakan sebagai daerah bekas terbakar di wilayah kerja Resort Tengger Laut Pasir. Berikut koordinat lokasi daerah bekas terbakar:

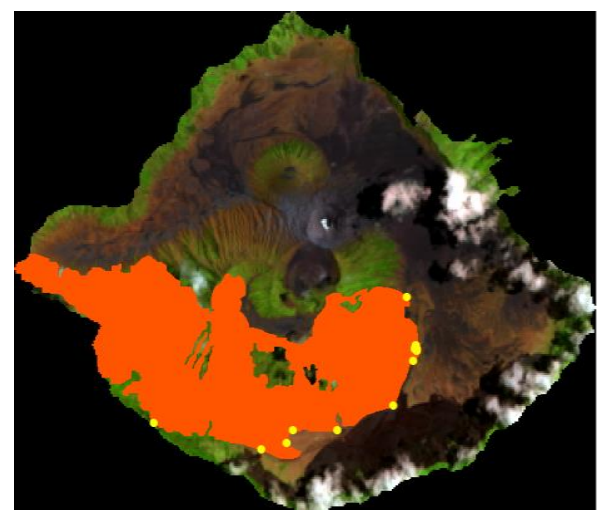

Gambar 4. Koordinat Lokasi Daerah Bekas Terbakar

Pengaruh kebakaran terhadap sifat kimia tanah adalah peningkatan bahan organik, nitrogen, dan mineral-mineral tanah segera setelah terjadi kebakaran. Namun demikian satu tahun setelah terbakar, unsur-unsur tersebut mengalami penurunan yang dapat disebabkan oleh pencucian, dimanfaatkan oleh tanaman, aktivitas jasad renik tanah dan tererosi. Bahan organik tanah biasanya diukur dari kandungan C-organic (Carbon Organik). Berdasarkan sampel tanah yang diambil pada saat groundtruth, didapat kandungan C-organic sebesar $19,501 \%$. Sedikitnya kandungan bahan organik pada tanah bekas terbakar disebabkan kebakaran terjadi hampir 2 tahun yang lalu.

\section{B. Perhitungan Nilai NDVI}

Perhitungan NDVI akan menghasilkan nilai $\mathrm{NDVI}_{1}, \mathrm{NDVI}_{2}$, dan $\triangle$ NDVI. NDVI 1 dan $\mathrm{NDVI}_{2}$ dihitung dengan (1) sedangkan $\triangle$ NDVI dihitung dengan (2). Nilai NDVI berada dalam kisaran -1 hingga +1 .

Tabel 2.

Nilai NDVI

\begin{tabular}{ccc}
\multicolumn{3}{c}{ Nilai NDVI } \\
\hline \hline \multirow{2}{*}{ NDVI } & \multicolumn{2}{c}{ Citra } \\
\cline { 2 - 3 } & Landsat-8 & MODIS \\
\hline
\end{tabular}

\begin{tabular}{ccc}
\hline $\mathrm{NDVI}_{1}$ & $0.023638 \mathrm{~s} / \mathrm{d} 1$ & $-0.223911 \mathrm{~s} / \mathrm{d} 0.482769$ \\
$\mathrm{NDVI}_{2}$ & $-0.029147 \mathrm{~s} / \mathrm{d} 0.977035$ & $-0.278992 \mathrm{~s} / \mathrm{d} 0.382526$ \\
$\Delta \mathrm{NDVI}$ & $-0.839660 \mathrm{~s} / \mathrm{d} 0.921252$ & $-0.397769 \mathrm{~s} / \mathrm{d} 0.587487$ \\
\hline
\end{tabular}

Peristiwa kebakaran akan mengubah tutupan lahan dari vegetasi menjadi lahan terbuka dan menyisakan bekas kebakaran. Perubahan tersebut mempengaruhi hasil perhitungan NDVI. Lahan bervegetasi memiliki nilai NDVI lebih besar dibandingkan lahan terbuka bekas kebakaran. Sehingga terjadi penurunan nilai NDVI pada daerah tertentu sesaat setelah kebakaran.

Tabel 3.

Rata-rata nilai NDVI sebelum dan sesudah kebakaran

\begin{tabular}{ccc}
\hline \hline \multirow{2}{*}{ NDVI } & \multicolumn{2}{c}{ Citra } \\
\cline { 2 - 3 } & Landsat -8 & MODIS \\
\hline$\mu \mathrm{NDVI}_{1}$ & 0.438901 & 0.143328 \\
$\mu \mathrm{NDVI}_{2}$ & 0.339704 & -0.038138 \\
\hline \hline
\end{tabular}

\section{Penentuan Threshold}

Penentuan threshold dilakukan dengan menghitung rata-rata $(\mu)$ dan standar deviasi $(\sigma)$ nilai reflektan dari 50 titik sampel citra Landsat-8 yang dianggap terbakar. Nilai rata-rata dan standar deviasi yang dihasilkan adalah 0.32002748 dan 0.116521449 . Nilai threshold yang dihasilkan adalah:

$$
\begin{array}{ll}
\mu-1 \sigma & =0.203506031 \\
\mu & =0.320027480 \\
\mu+1 \sigma & =0.436548929
\end{array}
$$

Setiap titik sampel memiliki nilai reflektan yang berbeda. Nilai tersebut menunjukkan tingkat keparahan daerah bekas terbakar. Semakin besar nilainya semakin parah. Oleh sebab itu, pemilihan titik sampel sebaiknya dilakukan di daerah bekas terbakar yang parah dan tidak. Jumlah titik sampel juga mempengaruhi nilai threshold. Semakin banyak titik sampel semakin baik nilainya.

\section{Identifikasi Daerah Bekas Terbakar}

Suatu piksel dinyatakan sebagai daerah bekas terbakar jika nilainya melebihi nilai threshold. Identifikasi daerah bekas terbakar referensi (estimated burned area) dilakukan dengan menggunakan (3). Berikut hasil klasifikasi daerah bekas terbakar dari model threshold yang digunakan:

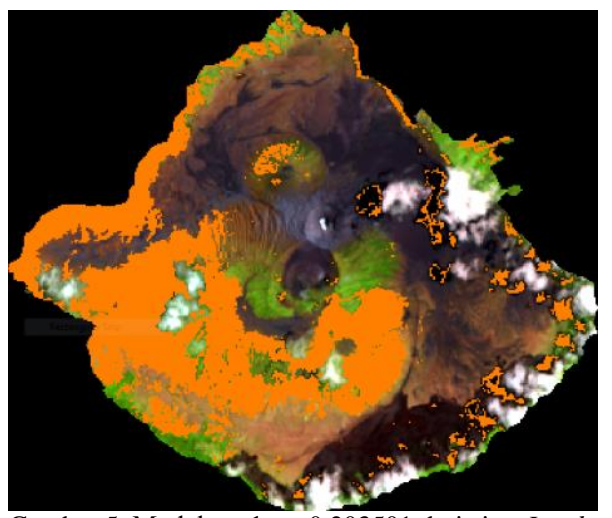

Gambar 5. Model $\mu-1 \sigma=0.203501$ dari citra Landsat -8 


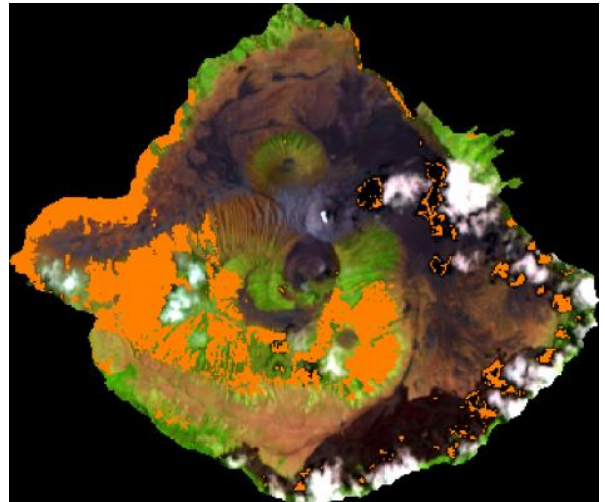

Gambar 6. Model $\mu=0.32003$ dari citra Landsat-8

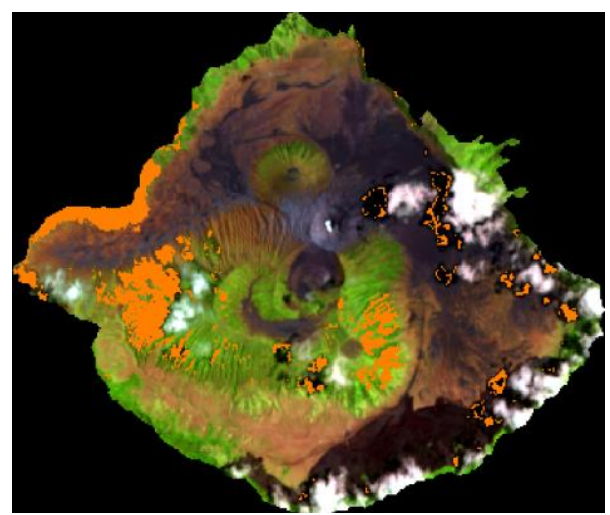

Gambar 7. Model $\mu+1 \sigma=0.43655$ dari citra Landsat -8

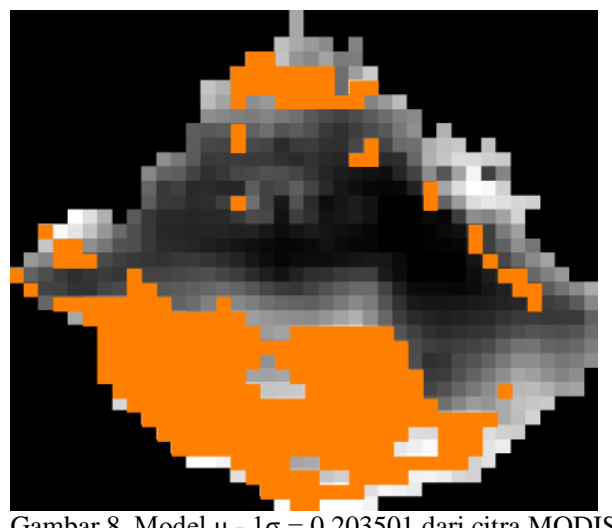

Gambar 8. Model $\mu-1 \sigma=0.203501$ dari citra MODIS

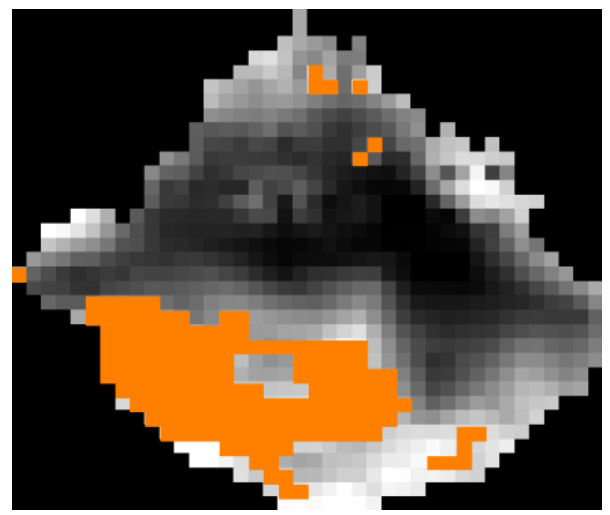

Gambar 9. Model $\mu=0.32003$ dari citra MODIS

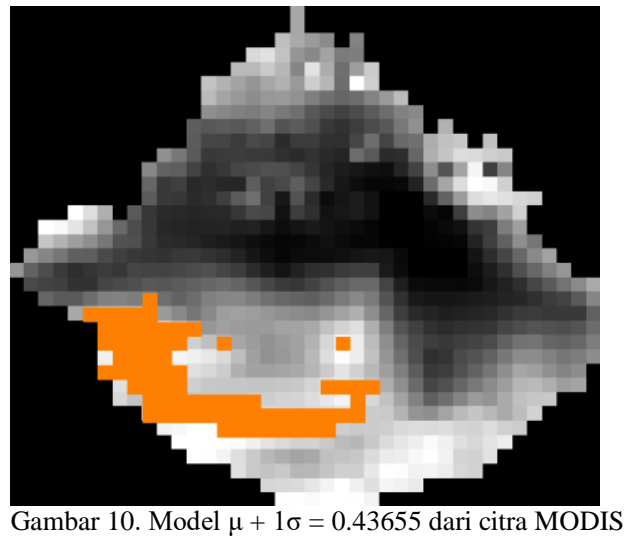

Hasil klasifikasi daerah bekas terbakar dipengaruhi oleh nilai threshold. Semakin kecil nilanya, semakin banyak piksel yang dinyatakan sebagai daerah bekas terbakar. Begitupun sebaliknya. Meskipun nilai threshold yang digunakan pada citra Landsat-8 dan citra MODIS sama, luas daerah bekas terbakar yang dihasilkan berbeda. Hal ini disebabkan oleh perbedaan resolusi spasial keduanya.

Citra Landsat-8 memiliki resolusi spasial $30 \mathrm{~m}$ sedangkan citra MODIS memiliki resolusi spasial $250 \mathrm{~m}$. Berdasarkan resolusi spasialnya, luas terkecil daerah bekas terbakar yang masih dapat terdeteksi (satu piksel) adalah $900 \mathrm{~m}^{2}$ dan 62500 $\mathrm{m}^{2}$. Namun, tidak berarti seluruh daerah dalam satu piksel tersebut merupakan daerah bekas terbakar. Bisa jadi daerah bekas terbakar kecil (kurang dari satu piksel) yang terdeteksi sebagai daerah bekas terbakar satu piksel penuh.

Tabel 4.

Luas daerah bekas terbakar

\begin{tabular}{ccc}
\hline & \multicolumn{2}{c}{ Luas Daerah Bekas Terbakar } \\
\cline { 2 - 3 } Threshold & Landsat-8 & MODIS \\
\hline$\mu-1 \sigma$ & $\mathbf{1 . 3 5 4 , 5 ~ H a}$ & $1.751,432 \mathrm{Ha}$ \\
$\mu$ & $794,79 \mathrm{Ha}$ & $\mathbf{1 . 0 0 5 , 2 0 9} \mathrm{Ha}$ \\
$\mu+1 \sigma$ & $357,12 \mathrm{Ha}$ & $437,848 \mathrm{Ha}$ \\
\hline \hline
\end{tabular}

\section{E. Uji Akurasi}

Uji akurasi dilakukan dengan membandingkan hasil identifikasi daerah bekas terbakar (estimated burned area) dengan data daerah bekas terbakar referensi (referenced burned area). Daerah bekas terbakar diprakirakan dengan melakukan kombinasi kanal citra Landsat-8 dan pengecekan koordinat lokasi daerah bekas terbakar dari laporan kejadian kebakaran BB TNBTS. Berdasarkan prakiraan tersebut, dapat dibuat daerah bekas terbakar referensi (referenced burned area) dengan melakukan delineasi. 


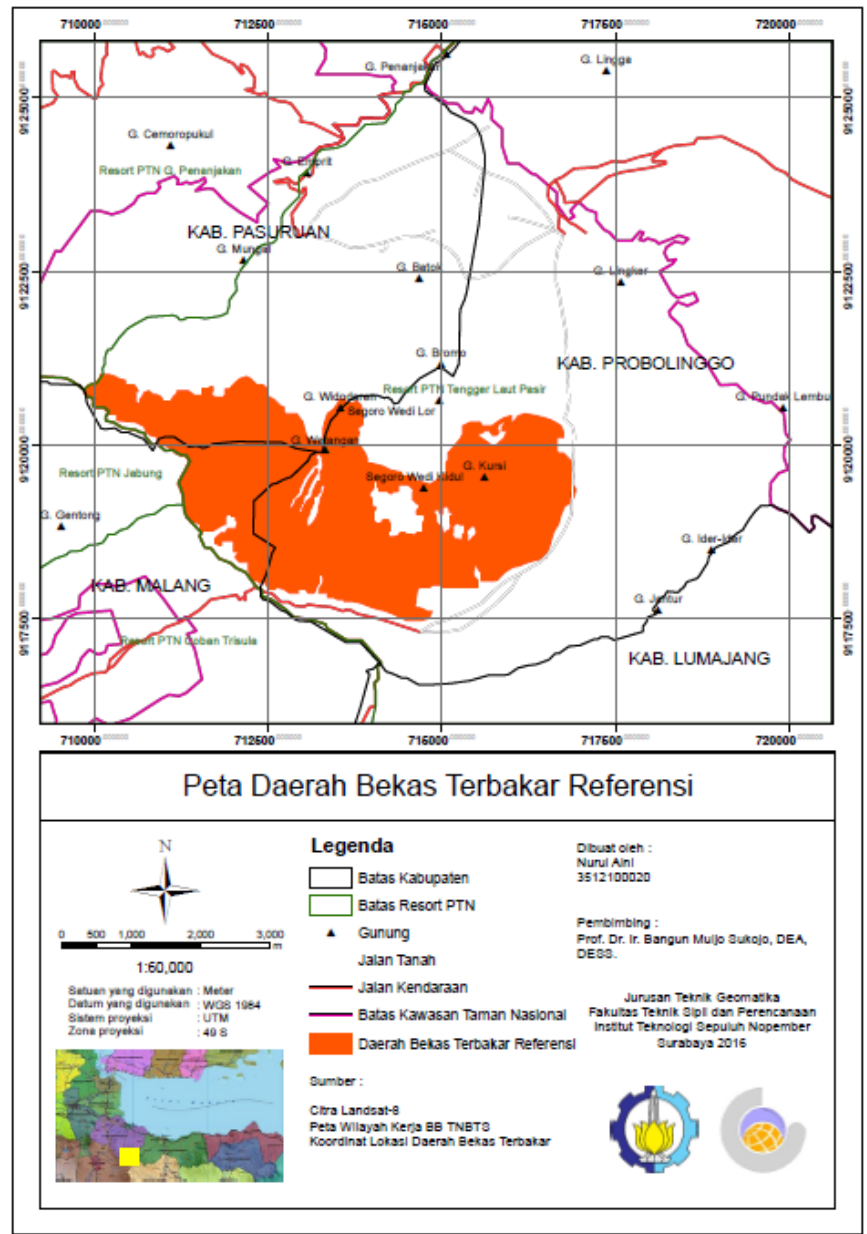

Gambar 11. Peta daerah bekas terbakar referensi

Berdasarkan data estimated burned area dan referenced burned area, dapat dihitung data valid, omisi, dan komisi.

Tabel 5.

Data valid, omisi, dan komisi

\begin{tabular}{ccccc}
\hline \multirow{2}{*}{ Citra } & $\begin{array}{c}\text { Threshol } \\
\boldsymbol{d}\end{array}$ & Data Valid & Omisi & Komisi \\
\hline \multirow{3}{*}{ Landsat } & $\mu-1 \sigma$ & $837,997 \mathrm{Ha}$ & $516,503 \mathrm{Ha}$ & $377,094 \mathrm{Ha}$ \\
8 & $\mu$ & $520,364 \mathrm{Ha}$ & $274,426 \mathrm{Ha}$ & $694,728 \mathrm{Ha}$ \\
& $\mu+1 \sigma$ & $206,519 \mathrm{Ha}$ & $150,601 \mathrm{Ha}$ & $1.008,572$ \\
& $\mu-1 \sigma$ & $969,504 \mathrm{Ha}$ & $781,928 \mathrm{Ha}$ & $245,587 \mathrm{Ha}$ \\
\multirow{2}{*}{ MODIS } & $\mu$ & $806,896 \mathrm{Ha}$ & $198,314 \mathrm{Ha}$ & $408,196 \mathrm{Ha}$ \\
& $\mu+1 \sigma$ & $420,574 \mathrm{Ha}$ & $17,274 \mathrm{Ha}$ & $794,518 \mathrm{Ha}$ \\
\hline \hline
\end{tabular}

Besar nilai akurasi dipengaruhi oleh nilai omisi dan komisi. Pada tabel di atas, nilai omisi dan komisi citra Landsat-8 dan citra MODIS terbilang cukup besar. Hal ini disebabkan oleh adanya tutupan awan dan bayangannya sehingga mempengaruhi nilai perekaman citra yang dihasilkan. Tutupan awan mengakibatkan suatu daerah tidak terdeteksi sebagai daerah bekas terbakar, sedangkan bayangannya mengakibatkan sutau daerah terdeteksi sebagai daerah bekas terbakar. Nilai akurasi dihitung dengan (4).

Tabel 6.

Nilai akurasi

\begin{tabular}{ccc}
\hline \multicolumn{2}{c}{ Nilai akurasi } \\
\hline \multirow{2}{*}{ Threshold } & \multicolumn{2}{c}{ Nilai Akurasi } \\
\cline { 2 - 3 } & Landsat-8 & MODIS \\
\hline$\mu-1 \sigma$ & $\mathbf{4 8 , 3 9 4 \%}$ & $48,548 \%$ \\
\hline \hline
\end{tabular}

\begin{tabular}{ccc}
\hline \hline$\mu$ & $34,935 \%$ & $\mathbf{5 7 , 0 8 9} \%$ \\
$\mu+1 \sigma$ & $15,122 \%$ & $34,127 \%$ \\
\hline \hline
\end{tabular}

Nilai akurasi paling besar untuk citra Landsat-8 adalah $48 \%$ dari model $\mu-1 \sigma$ dan untuk citra MODIS adalah $57 \%$ dari model $\mu$.

\section{F. Peta Daerah Bekas Terbakar}

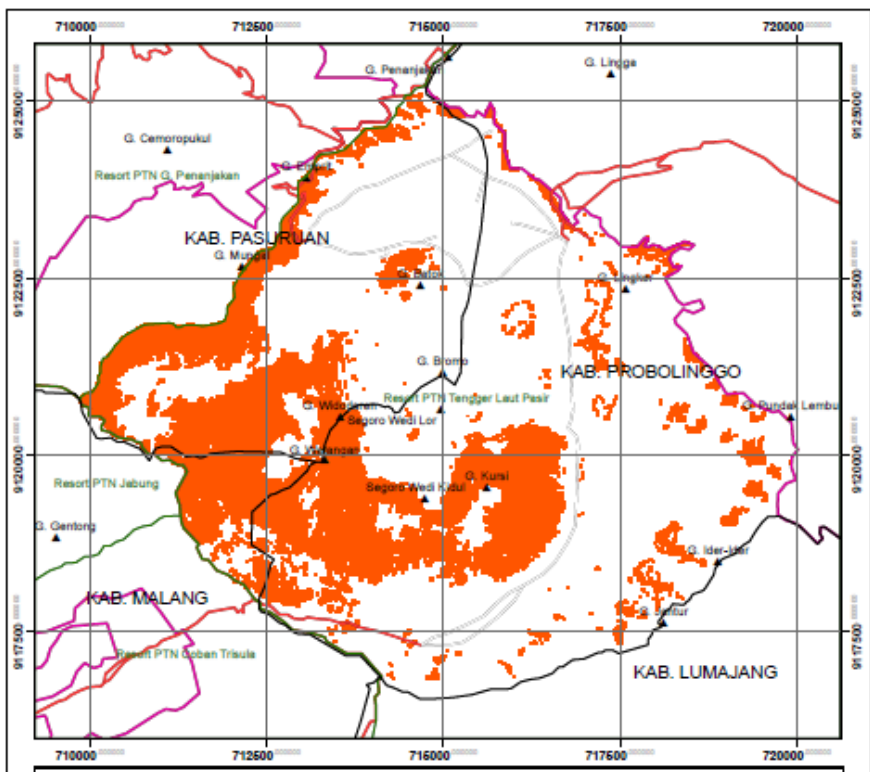

Peta Daerah Bekas Terbakar Berdasarkan Citra Landsat-8

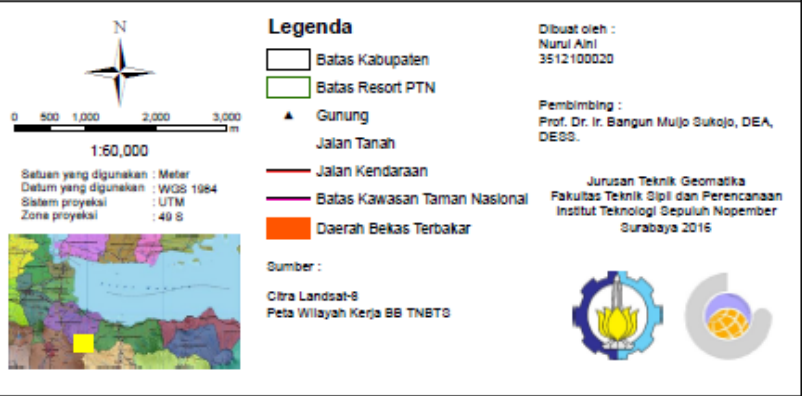

Gambar 12. Peta daerah bekas terbakar berdasarkan citra Landsat-8 


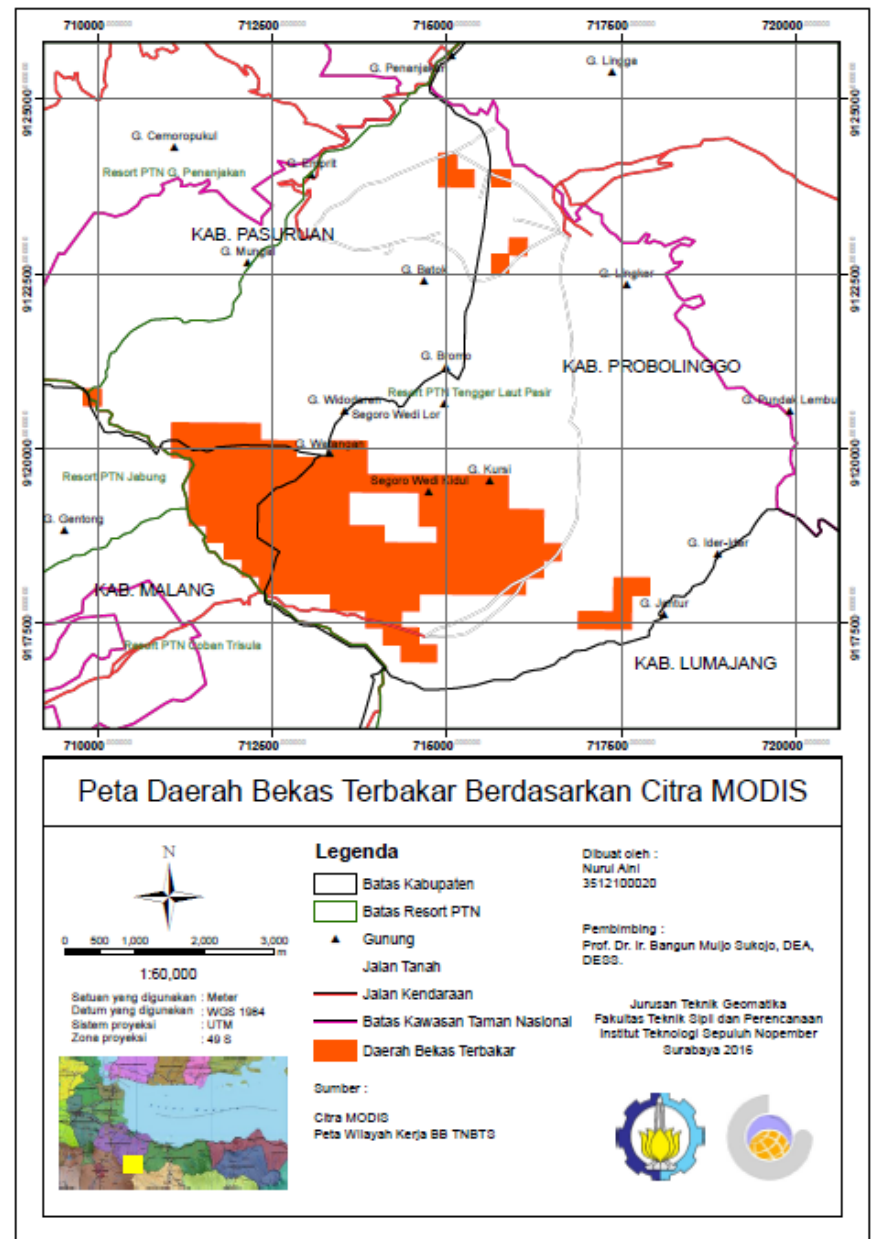

Gambar 13. Peta daerah bekas terbakar berdasarkan citra MODIS

\section{KESIMPULAN DAN SARAN}

Kesimpulan dari penelitian ini antara model threshold paling baik yang digunakan untuk mengidentifikasi daerah bekas terbakar dari citra Landsat-8 adalah $\mu-1 \sigma$ sedangkan citra MODIS adalah $\mu$. Nilai akurasi hasil identifikasi daerah bekas terbakar dari citra Landsat-8 adalah 48,394\% sedangkan citra MODIS adalah 57,089\%. Luas daerah bekas terbakar dari citra Landsat-8 adalah 1.354,5 Ha sedangkan citra MODIS adalah 1.005,209 Ha.

Adapun saran untuk penelitian selanjutnya antara lain identifikasi daerah bekas terbakar menggunakan citra MODIS sebaiknya dilakukan di daerah yang luas. Hal ini dimaksudkan agar daerah bekas terbakar pada peta terlihat lebih smooth. Data citra yang digunakan sebaiknya data citra yang bersih dari awan karena tutupan awan dan bayangannya akan mempengaruhi nilai perekaman citra. Data daerah bekas terbakar referensi yang dijadikan acuan sebaiknya di delineasi dari citra satelit resolusi tinggi. Daerah bekas terbakar dari citra satelit resolusi tinggi akan terlihat jelas secara visual sehingga memudahkan proses delineasi.

\section{DAFTAR PUSTAKA}

[1] Artha, F. 2011. Studi Perbandingan Sebaran Hotspot dengan Menggunakan Citra Satelit NOAA/AVHRR dan AQUA MODIS. Surabaya: Institut Teknologi Sepuluh Nopember.
[2] Huete, A., Justice, C., \& Leeuwen, V.W.,1999. Modis Vegetation Index (MOD 13) Algorithm TheoreticalBasis Document, University ofVirginia,Department of Environmental Sciences, Charlottesville, Virginia. 